\title{
A Review of Ethics of Public Administration
}

\author{
Kemi Anthony Emina \\ Department of Religious Studies and Philosophy, Delta State University. \\ E-mail: eminakemii@yahoo.com
}

(Received: March-2020; Reviewed: March-2020; Accepted: March-2020;

Avalaibel Online: March-2020; Published: March-2020)

This is an open access article distributed under the Creative Commons Attribution License

CC-BY-NC-4.0 @2020 by author (https://creativecommons.org/licenses/by-nc/4.0/)

\begin{abstract}
This work attempt to apply ethics to the field of administration. Philosophy, when analysed for its social nature have the potential of shaping the foundation of social nature and forming a more rational outcome. However, much as been said on the ethics of public administration, this work joins the discussion by analyzing several philosophical arguments concerning the ethics of public administration. This work restricts its scope to the application of the standard normative theories which has been advocated by a selected number of philosophers which this work holds in esteem. This research was carried out with the philosophical method of textual analysis.
\end{abstract}

Keywords: Public administration; Philosophy; Applied Ethical Theories; Altruism; Egoism.

\section{INTRODUCTION}

Initially, in the western part of the world the application of ethics has been some kind of practical involvement with theoretical or normative ethics. Peter Singer (1993) famously wrote that applied or practical ethics is but the application of standard theories of ethics to solve our moral dilemmas likes abortion, killing animals for cosmetic purpose and so on. Over time Peter Bryne (1999) and others argue that practical ethics is a quantum leap from the erstwhile application of ethics. The confusion with the application started with the ambiguous use of ethics and morality. A number of people started thinking that ethics is all about our moralities, the dos and don'ts, the traditionalist right and wrong or more clearly relics of our traditional conceptions of what are good, right, just, and so on. It is cultural so to say; relative and we just go by our own ways or forms of life. However, this is as misconceived as ethics is all about sexual prohibitions, purism, and abstinence and something that would eventually lead us to selfhood. The moment philosophers with their zeal to reveal truth start philosophizing we could see that ethics truly speaking is a branch of philosophy which aspires for philosophical analysis of moral issues.

This may be well explained with an example given by Herodotus in his History. As stated in this book Herodotus went to the Collations to know and discover that traditional morality is to consume their dead fathers may be for revitalizing their blood with their father 
spirit. Herodotus also discovered that the Greeks did not eat their fathers. However, both traditions thought that their deeds were -moral (in this sense it means what is ethical! (Sidgwick 1884). The point is Herodotus wanted to show is the truth of cultural relativism and relativistic moral conceptions, however, he stopped short of mentioning that there could be deep philosophical reflection on the entire moral issue which is the new phase of ethical reflection. Frankena (1989) is of the opinion that the application of ethics is something very interesting and important given our value-loaded maladies of life. However, the entire process of ethical application starting from pre-corroboration social research and even transcends the limit of what we may call, -practical ethics. Practical ethics is not anything like a lab work by pseudo-scientists; it simply means the ways in which we the people in association are able to work in laden to practically press on our moral experience and knowledge to resolve issues of moral urgency.

The reason for this work is to discover the application of ethical theories in case of administration/management/ leadership and so on. I would unravel the nature and features of theoretical application of ethos in administration. And for this the best way is to underline normative theories that were enthusiastically applied by a number of thinkers over the time, more popular as -value paradigm in resolving moral crises in administration and management.

\section{WESTERN APPLIED ETHICAL THEORIES AND ADMINISTRATIVE ACTIONS}

There are a number of normative theories which come under application in resolving a gamut of value loaded practical problems. In fact these normative principles are applied not merely symbolically to reform models in public administration but are also helpful in finding out the flaws that unilateral application of these theories have in the field of administration so that people can slowly move towards the realisation of a pluralist approach to ethical application.

\section{Altruism vs Egoism Argument}

The foremost ethical principle that has been applied widely by administrative philosophers and administrators is the theory of self-interest or what is technically known as egoism. Egoism or self-interest theory, however, should not be confused with selfishness theory and egotistic theory because the former is a theory that speaks about self-regarding acts as supreme at the cost of damage to or complete disregard about self- interest of people other than me, whereas the latter theory speaks of gratification of pleasure of an agent in consideration (Ogar \& Ogar 2018). In fact, Interest of the self is not merely gratification or the pleasure. There may be many non-hedonic goals that might be very helpful to satisfy the condition of selfinterest. I may be interested in friendship, knowledge, and many other things which are of my interest. This normative theory, historically, has played a crucial role in the history of liberalism, neo-classical political economy, and in political science when we come to the issue of rational choice. Self- interest theory when applied to administration simply states that the state agents or civil servants should act like members of the diaspora who normally acts in a rational self- interested manner. This has been stressed by thinkers like Jeroen Maesschalck and Shamsul Haque (2007). However, the theory was formulated and applied by Bernard Mandeville as well as Immanuel Kant when Kant famously says that only if people have rational understanding they can resolve the problems regarding states. It is interesting to note that when Kant made this comment the theory of self-interest was established well in the writings of political liberalism. 
In stark contrast, we have the theory of Max Weber which is found in Weberian conception of State and in Hegel's criticism of Kant regarding the above comment. Particularly, in the context of the traditional republican values of patriotism Hegel clearly defined the role and importance of altruism than egoism in civil service. However, such altruism of the civil servants is not based on a great presupposition of goodness of character rather Hegel has conceived of a particular institutional structure that is important for the safeguard of autonomy of civil servants and of the state which Hegel has called self-interestedness for civil society. However, Hegel's attitude owes much to French revolution in as far as he sidesteps altruism because it is probably an unworthy motivation though much desired on the part of civil servants who enjoy a paternalistic authoritarian position in society. Or the same is glorified as a religious virtue or a great moral property. Instead of these attributes Hegel has extensively referred to the concepts of virtue and patriotism of the republican tradition which had its roots in French revolution. Virtue and patriotism are the two concepts needed to motivate active citizens in republic which was well articulated by Machiavelli in his The Prince.

Later on, Lorenz von Stein was influenced by Hegel's thought and he tried to revert the administrative activities of the state as some kind of technical discipline called: cameralism. Stein conceived the state having autonomy separated from an individual a particular ruler so to say and thus severed the self-interestedness which was prevailed during his time. Hegel's argument against the application of self-interest in administration of an organization is that it causes poverty in industrial cities whereby a whole class of workers are politically marginalised and thus instead of a civil society we get a self-oriented society of the elites. Hegel, therefore, makes a call for public reaction and revolt against such poverty causing great deprivation of the industrial poor as well as deprivation of the poor in terms of political freedom and intellectual growth. Stein says that the political freedom of the individual is guaranteed constitutionally in the modern states. Therefore, administration has a task for it to afford the benefits guaranteed in the constitution. Such legal guarantee can be ensured by social administration rather than self-interested individualistic arbitrary administration that causes industrial poverty. The impacts of Hegel's and Stein's rejection of self-interested theory in civil service brought serious attention in the United States which can be well noted in the works on public administration authored by Woodrow Wilson and Frank Goodnow (1997).

The application of the self-interested theory in the civil service has found a contemporary critique particularly in the field of political science when some of the thinkers hold that social agents do act in self-interested way in a market context that is in market economy but the same need not be and cannot be applied in the spheres of politics and governments (Ogar \& Ogar 2018). Research has shown that methodologically self-interest market economy and self-interested politics and governance are in no case one and the same. Rather researcher E. Ostrom (2000) concludes that normative principles of self- interestedness are an - arbitrary theoretical assumption for public administration. E. Ostrom concludes that altruism has a good chance to flourish among social agents which lays basis for a -positive ethics of public administration in ethics, which concerns itself with the avoidance of undesirable behaviour like corruption and dishonesty by an individual who is guided by the thought of self-interest and is detrimental to ethical public administration. The positive ethics of public administration construed by E. Ostrom and others focus is on the conditions and circumstances that are responsible for the altruistic behaviour in public servants as well as NGOs in his work, the spirit of public administration. Frederickson (1997) argues that the role of public administrators in championing civil citizenship participated in democracy and value 
sensitivity of social equality and benevolence are of great value. He argues that there is every chance to patronised and lead to benevolence if we do care about altruistic administration.

Although much has been said about the voices of political liberalism and rational egoism we have to find out who are its main supporters and why. One of the old ideas very popular during Scottish enlightenment is that self-interestedness and the values of pride, envy, vanity are sources of public good because such private vices are sources for public good because people get united, organised against self-interested people. However, a more sensible rational egoism was proposed by Bernard Mandeville but made famous by Adam Smith who had coined a theory of the -invisible hand that is the hand of selfishness which governs a dynamic market economy must be for this reason he better known as the founder of modern economics. Another reason of is rhetoric of invisible hand is the hand of selfish interest that results in public good because it coordinates the self-interested people contextually for the betterment of their own selves but invisibly does good to the society. This is the raison the arete of political liberalism and liberal economics of the present day.

Interestingly, this influence of self-interest in public administration is well noticed in John Rawls' A Theory of Justice which is known to be one of the best examples of contemporary political liberalism. Rawls says that in -an original position people that are social engineers when they are in a -veil of ignorance justice is possible (Udoudom \& Bassey 2018). Hence, in a liberal society groups of reasonably self-interested people can deliberate on a set of principles that may be adopted to govern an ideal society. However, these parties only aim at their individual best results in an ideal society they are going to live. The point of departure is that they do so in association through debating while putting themselves under a veil of ignorance that is ignorance about the talents and fortunes, ethnicity, gender, and religion of the parties who are going to live in an ideal society. However, this is not a realistic conception under the changing specific circumstances that each and every rational egoist will aspire for an ideal liberal society. On the contrary, such political liberalism might result into greater evil that no one in such an assumed society will be altruistic and benevolent, however, reasonable they are. Bereft of altruism and benevolence, public good is a distant cry and the imagined cooperation of people having self-interest in a rational way for public good is altogether a hopeless idea (Bassey et al. 2018).

Astonishingly, the predecessors of such alleviated self-interest of the Rawlsian statures has been advocated by Kant when he declares even devils can be of understanding nature to solve the problems of a state. It is not easy to understand though how devils (self-interested people) can be of understanding (rational) nature to establish a prosperous state and even if it happens it only leads to individual benefits. Rational self-interest rather, leads to nonenlightened legislator who do little good for public good. A similar Kantian approach is found in the works of Rawls where rationality needs pursuance of self-benefits and not public benefit. However, Kant's liberal theory was a little subdued during the late $19^{\text {th }}$ and the first half of the $20^{\text {th }}$ century due to the utilitarian pressure of political liberalism championed by John Stuart Mill who did not support rational self-interest the way in which Kant and Rawls did because the utilitarian presupposition of Kant is partially based on psychological hedonism but best understood in terms of his heuristic argument of rationally accepting that despite selfinterestedness we transmute to altruists by virtue of a number of external and internal sanctions (Ikegbu et al. 2009).

With the advent of democracy and political liberalism during the $20^{\text {th }}$ century, a number of thinkers like Habermas proposed deliberative democracy (Ferraro \& Ajenjo, 2014: 10) or 
what is -constitutional patriotism wherein the supreme motivation is a political participation by abstaining from self-interestedness in private life and in economic activities. However, the debate between liberalism and democratic patriotism that is the Rawlsian and Habermasian debate still alive because the basic question of the relation between state and its citizens are radical enough (Bassey 2016). For one individual citizen, it's just a part of the whole and for the other; the individual citizen is whole and soul of what we call State.

They attack of altruism and the conception of Weberian State goes quite against what has been said thus far. Hegel says that when civil society becomes individualistic for larger benefits it results into isolation and narrowness and class-conflict arises. There is an air of uncertainty among the public because the public institutions come to worse to worse situation and a class of people gains strength. Then Hegel, Ferraro and Ajenjo (2014. 12-13), remarks: between the state and the individuals there is not a natural and direct link; the individuals are not appointed to office on account of their birth or natural personality. The objective factor in their appointment is knowledge and proof of ability. Such proof guarantees that the state will get what it requires; and as the only condition of appointment, it also guarantees to every citizen the chance of joining the class of civil servants. Clearly the class of civil servants gets detached from the governed day by day when individual self-interest is at its extreme. However, the point is that professional public service is something that comes from a covenant between the public and the individual that is the state and the individual and it is this relationship that defines the livelihood and success of the public servants. And therefore he says: -the service of the state requires the sacrifice of the personal and discretionary satisfaction of subjective ends, and it provides precisely by virtue of this sacrifice, the right to find such satisfaction in, but only in, and the proper discharge of dutiesll. (Ferraro \& Ajenjo, 2014: 13)

In the midst of the debate between the conceptions of self-interest and altruism in State and administration we have to get somewhere. Ferraro and Ajenjo conclude that there is a third normative approach that may be applied in this contesting climate they call it an approach of rational choice and cooperative behaviour which assumes four components of individual's behaviour which arefollowing:

1 Individuals are aware of their own order of preferences; and they have a constant discount factor, which is always monotonically increasing over time;

2 Individuals are also aware of alternative decision methods and opt for the one which offers them the best fit between efforts and results, employing the principle;

3 Individuals care for others' order of preferences, but the last word in each interaction depends on how repeated it is expected to be over time;

4 Individuals are able to choose a second-best option if meta-preferences are at work, that is, emotional, intuitive or other signals of this type are only relevant when discussion over outcomes occurs (2014: 17-18).

These four principles they say, act as -grammatical rules that is, hold by many though with exception that enhance our proficiency in both choice and behaviour that is in choosing and behaving in the climate of organizational governance and administration. It accepts the relativistic truth that both choice and behaviour have exceptions due to different social settings or interaction among individuals because they have different procedures of bargaining, decanting, accepting, or dissolving in social context. However, E. Ostron finds out some of the outcomes of accepting this equilibrium between rational choice and cooperative behaviour because a number of individuals might have intrinsic preferences regarding how they ought to behave in situations that demand collective action for public benefit. E. Ostrom's 
observations resulting to revised theory of collective action one important factor being that the characteristic of changing contexts is equally important as the individual rationality operating among changing contexts resulting into some sort of cooperation-non-cooperation outcome. In this regard, collective cooperation has a better chance when public bureaucracy we have to acknowledge some facts in order to have a proper cooperation between the weaknesses and strengths of rational choice model. This results into inclusion of an -informed view on collective action within public administration. Ferraro \& Ajenjo writes: -these facts refer to: called repeated games, where cooperation is more prone to become a valued good);

2 Their space is common so every unacceptable or conflictive behaviour is clearly observed (prestige is a valued good);

3 The rules of operation are exogenously settled for all equally (there is no primus inter pares rule, or, equivalently, there is equal career advance for equal competencies and abilities); (2014: 20)

Evidentially, the context dependents conditions where bureaucracy works adopts different forms where the livelihood of favourable cooperation among the otherwise selfinterested parties depending on trust, and reciprocity is quite possible.

Given the possibility of altruistic cooperative behaviour, there is a chance that civil servants despite self-interestedness might cooperate for public good. The authors believed that this is possible by at least three important means: first, intangible rewards in civil service careers that are an order for a system of intangible rewards to retain political and philosophical legitimacy in the face of wayward liberalism. The authors say that, such a system is well in place in Britain and France. Further, the authors mention about community and networks among public officials and the NGOs. They are of the opinion that for better governance that sidesteps the conflict between self-interest and altruism, liberal thinking on the part of public officials may be extended to promote the inclusion of the members of non-government organizations for best results in civil service. Finally, they suggest community and voluntary service as professional qualification that is a civil servant is expected to work a mile for the social good and in order to rectify relics of their individualistic self-interestedness.

We have mentioned before that a number of thinkers believe in non-normative approach to application to resolve problems of concern. It is worth mentioning that Mark Lilla (1981) argues that the attempt to equipped public servants with normative theories to rationalise their conduct is not a good idea. He argues that the administrator should inculcate a set of virtues derived from a democratic ethos. However, it will not be a worthy situation to say that inculcation of a set of virtues would be sufficient for value- based administration. It is interesting to know in this regard that William Frankena in his work Ethics (1989) mentions that each of the assumed virtues that have to be inculcated begs a normative assumption. In place of forceful and unilateral virtue ethics some people argue that a complete normative ethics for public administration should include a proper understanding of ethical principles, virtues which are supportive of those principles should be identified, and specific situations have to be cared for to interpret the applicability of principles (Bassey \& Mendie 2019). One of the important virtues needed of an administrator is to act upon principle despite consequences which may be not so desirable.

The champions of virtue ethics however, should be treated carefully before a judgment has to be passed. Particularly, in the context of organizational hierarchy that is evident across the globe. The hierarchical arrangement of modern organizations and the problems that the 
hierarchy creates has been taken care of Alasdair MacIntyre (1984) when he suggests the concepts of practices and their virtues. A number of scholars after McIntyre however, demands for revision of the idea of MacIntyre in order to accommodate normative features in administration. Anyway, we have to listen to MacIntyre first. He focuses on -practices rather than -professions when the question of ethicality of a group of people say administrators involved in common activities. He says that practices are forms of activities nota le for the following characteristics: -

1 .

They exhibit coherence and complexity.

2.

They are socially established.

3. They are carried out through human cooperation.

4. They involved technical skills which are exercised within evolving traditions of value and principles.

5. They are organized to achieve certain standards of excellence.

6. Certain internal goods are produced in the pursuit of excellence.

7. Engaging in the activity increases human power to achieve the standards of excellence and internal goods.

8.

Engaging in the activity systematically extends human conceptions of its internal goods.ll (Cooper, 1987: 321)

He explains that the range of practices is wide whereas the range of profession is not that wide. In his own words: -the range of practices is wide, including -arts, science, games, politics in the Aristotelian sense and -the making and sustaining of family life. (Cooper, 1987: 321) the reason being that practice has a larger framework within which we can develop a normative perspective for public administration. If you look into public administration as mere profession, we often get an idea of self-interestedness, self- protection, self-implosive nature and a paternalistic expert attitude which is often believed to be much needed for the running of a democracy. However, if we look in the perspective of practice we get a broader framework of administration that escapes the defects of paternalism and class conscious activities. In fact, the perspective of practice includes professional practices and a number of other human activities. Where we consider the notion of practice in the conceptual framework of ethical problem solving related to organizational hierarchy we understand better how important public administration ought to be taken in term of a practices that transcends the limits of an employment with duties and obligations ear marked by public organization. The author mentions eight characteristics of practices that constitute a normative framework that is profitable to guide reflection about public administrative role. We can briefly study these dimensions that might help in making some kind of hand shake between normative thinking and virtue ethical thinking.

The first point is to note the internal good of a practice that is in order to understand well the nature of the practices we have to understand the internal good related to those practices. Such good things are realized only when we participate in a particular practice for example, when we participate in a particular administrative practice we know what is internally good to that practice. All goods that are internal to practices are acquired that is they are gained by engaging in a practice otherwise not. This has an Aristotelian flavour to it because in becoming good we have to do well. The point is whether public administration should be understood as a practice at all? And if it is a practice what internal goods do we conceive related to that practice. The internal good of public administration is to take care of public interest 
sovereignty, accountability, order in society, and justice in society, development of civil society, socio-political equality, efficiency, and liberty (Ikegbu \& Bassey 2019). When we come to these we clearly understand that public administration relates to certain internal virtues or values which in turn give us the idea of a range of practices conceivable for public administration. However, there is a lot of disagreement among what these internal goods mean and which one should take priority. Further, if we consider these internal goods that ear marks the practice of administration it will be very difficult to distinguished public administration and business administration due to the evident overlapping of the values and therefore the practices.

The author however, is careful about mentioning the external goods of a practice. External goods different from internal goods are those which we achieve in a number of ways even if we do not participate in a particular practice. We can say that the external goods are necessary for say administration but they do not contribute directly to the growth of that practice such as money, prestige, self-esteem, power, and position and many others. However, external goods become objects of competitions wherein the hierarchy scenario features with its winners and losers. It is different from gaining or acquiring virtue as it were in the case of internal goods. Therefore, there are thinkers who believe along with the author that though administrators do have goals to achieve the external goods it should not indulge into practices that supersede the very idea of internal goods because practices should be better oriented towards the development of the internal goods as MacIntyre believes. Another point is that, the internal goods of a practice are often in a risk situation in an organization which for reasons has been dominated by external goods. This prevalence of external goods than internal goods put the administrative practice in the serious position.

However, the author having considered the development of the internal goods and external goods give greater importance to the development of a set of virtues and practices. Though not leave completely the very ideas of the development of the internal and external goods in public administrative practice. Together this idea is fundamentally a normative thinking. Public administrators, according to MacIntyre, Hampshire, and even W. K. Frankena, should determine the set of attributes which are most likely to advance the internal goods which are essential to administrative practice and protect them from organizational and external pressures. The point is the public administrator must be aware of agreed upon an internal practice of public administration.

The author gives us a classical paradigm of the practice of public administration that takes care of internal goods over and above external goods which he owes to Mark Moore's paper Realms of Obligation and Virtue.

Table: The Practice of Public Administration

\begin{tabular}{|l|l|l|}
\hline Realms of Obligation and Virtue & Internal Goods & Virtues \\
\hline bligation to pursue the public interest & Beneficence for citizenry Justice & $\begin{array}{l}\text { Benevolence Courage } \\
\text { Rationality } \\
\text { Fairmindedness } \\
\text { Prudence }\end{array}$ \\
\hline
\end{tabular}




\begin{tabular}{|l|l|l|}
\hline $\begin{array}{l}\text { bligation to authorizing processes and } \\
\text { procedures }\end{array}$ & $\begin{array}{l}\text { Popular sovereignty } \\
\text { Accountability } \\
\text { Rue process } \\
\text { Ronesty } \\
\text { Self-discipline } \\
\text { Civility }\end{array}$ \\
\hline 3. Obligation to colleagues & $\begin{array}{l}\text { Enhancement of standards of } \\
\text { excellence } \\
\text { Contribution to achievement of }\end{array}$ & $\begin{array}{l}\text { Fair-mindedness } \\
\text { Trustworthiness Respect } \\
\text { for colleagues } \\
\text { Responsibility for } \\
\text { Civility Honesty } \\
\text { Prudence Rationality } \\
\text { Independence }\end{array}$ \\
& & \\
& & \\
& & \\
\end{tabular}

Cooper then clarifies that the practice of public administration combines in its normative thinking the realm of virtues or obligatory virtues such as to look after the public interests, authorizing processes and procedures, and good of the colleagues. Corresponding to each of the obligatory virtues, he notes the internal goods such as beneficence, sovereignty, and excellence. Naturally, therefore these internal goods relate to inculcation of virtues, notably, for the first one benevolence and courage for the second one respect for law and rationality and for the third one, fair mindedness, and trustworthiness.

Having said all these Cooper much in the line of Frankena tries to balance between virtue theory and normative theory. In fact, the very texture of normative thinking coagulates the internal goods and inculcation of virtues that is so much so needed for an administrative practice. Thus far we have been dealing with the normative and virtue ethical approaches in public administration we can now take the feminist ethical approach of care and compassion to justify how important these principles are in organizational leadership and justice. It has been widely and sensitively shared by a number of thinkers in the recent times that individual's personal life does affect their professional outcomes at the workplace. If this is the case, the organizations should be doubly careful for a great responsibility to end the sufferings of people and promote collective well-being. Care and compassion has been given great attention by thinkers like Eddington (2010), Margalit (1996) and others. The concern for care and compassion in organizations play a pivotal role in sustaining common good, strong social relationship, greater individual responsiveness, and reciprocity. However, care and compassion in organizational administration have been severely attacked for being limited, favouritism, vulnerable to emotions, and jeopardizing fairness and justice. A number of thinkers on organizational justice suggest that though a fair and equitable equipment of employees do have 
positive impact on productivity and commitment and equality and justice have been identified as strongly valuable in organizational outcomes and social relationships. Despite that many contemporary scholars have declared that care and compassion clash with principles of justice determinates the implementation of justice in organizations. If this is the case the tussle between justice and compassion jeopardizes organizational decision-making because justice needs objectivity fairness, equality, and rules that ought to be followed and rejects the feminists' notions of care and compassion in decision-making. Weber, for instance, thinks that a leader if overplays with personal relationships care, compassion and things like that is liable to abuse of power, favouritism and inefficient at the organisational level. In this climate, a new approach is needed to integrate the principles of compassion and justice to allow administrators in organizations to take advantage of both justice and compassion. How can the balance between the contesting principles be obtained is the moot problem.

Normally, compassion is defined in relation with different emotions and feelings like pity, empathy, care, responsive to suffering of other people etc., Interestingly, there are fundamental philosophical differences about compassion in religions but across religion it is defined as a great human virtue whether it is Islam, Christianity, Hinduism, Buddhism, and Jainism and so on. Similarly, organizational justice has been conceptualized with the work of Adam Smith's equity theory and others' equity theories later on. Festinger (1957) who has influenced Adam's things that justice and equity is basic to the conceptions of fairness and equality which is again basic to the notion of fairness at the work place. Other thinkers like Miles have further given us the concept of equity sensitivity that is people's response to inequalities due to the different levels of their sensitivity towards situations causing inequality. It has been said that organizational justice refers to fairness perceptions that people hold about decision-making and resource allocation processes in organizations. However, in the recent times organizational justice is perceived as distributive justice procedural justice, interactional justice and informal justice. Distributive justice is all about fair distribution and allocation of rewards and resources. Procedural justice is a fairness process to distribute and allocate resources and rewards in direct link with equity theory. Interactional justice is a component of procedural justice in which opportunity to interact between decision-makers and authorities which are basic to organizational justice. And offshoot of interactional justice is informational justice that refers to degree of fairness of information gathered.

Further on organizational justice has been perceived as either static or dynamic. Static organizational justice is based on pre-determined rules and objectives whereas dynamic justice refers to essence of purpose of procedures that takes care of change and development. It is exactly at the point of dynamic justice that the ethic of care and compassion shows its importance because in doing dynamics justice people form their caring and compassion behaviour with regard to others who need justice.

Principles of care and compassion show their dynamic nature universally which is however, not true about organizational justice because it can be both static and dynamic and thus incompatible to each other. Hence, the incompatibility between principles of justice and those of care and compassion does not stand good in as far as we perceive of organizational justice in its very dynamic nature. Therefore, dynamic justice is in close relationship with the dynamicity of care and compassion of the leaders of an organization. This is also clear that care and compassion are essential requirements of the society because it is not mere sympathy and contract between people that society comes into an existence and stands in a sustainable nature. If care and compassion are pillars of the very existence of the society justice is built upon the 
ideas of fairness and equality and rule of law. These are the elements which have to be equally cared upon because no care about fairness, equality, and rule of law leads to non-existence of a civil society. Eddington (2010) argues that compassion helps in developing humane policies and justice that safeguards the sufferers of the society. It would be proper to think that justice is rational, logical, and so is human compassionate behaviour because care and compassion comes out of a delicate thinking process where contextually the relevance and importance of care and compassion are rationalized. In our times, therefore, we do think about emotions that are reasoned, human emotions divorced from reason is living in a fool's paradise. Eddington therefore, combines positivistic conception of organizational justice with what he calls 'intelligent emotions' -which is very similar to the notion of emotional intelligence. For instance, fairness heuristic theory explains the role of subjective judgment in developing fairness perceptions which they draw on through their social interactions with seniors, colleagues, and top management, (Shahzad et al, 2014:174) which we now know popularly as emotional intelligence. Thinkers like Lind, and Crisp therefore, argue that in organizational hierarchy subjective judgment in developing fairness perceptions emerge out of social interaction among the members of the staff. Therefore, the requirement of justice or what is the claim of justice is based on the principles of care and compassion. In this way, the emotive principles and the principle of justice are well applied in the field of organizational administration.

\section{CONCLUSION}

From the above, we have seen devise argument from philosophers point of view on ethics of public administration. This paper is of the opinion that the application of ethics is best instantiated in social leadership or in institutional administration and management. Though, virtue is of a great importance for an administrator he cannot overplay with it because often a virtue approach makes an administrator over confident with his righteousness and noble character. Therefore, there must be certain check and balance of principles to decide on what to do and what not to do. These normative principles when applied contextually; find tunes the virtues of an administrator and makes him more responsible towards decisions and actions. Nevertheless, a morally good administrator must have strength of character when he faces moral dilemmas in problematic situations. It is in this regard that applying the virtues of - honesty, benevolence, respect, responsibility, and prudence are of great importance. However, if wellbeing of the public is the supreme importance, the virtuous administrator must have acumen to examine the results of his decisions in each and every context. He must have the wisdom to analyse the decisions whether those good favourably or adversely affect his superior workers, family, and the society at large.

\section{REFERENCES}

Bassey, S. A. (2016). Democracy and Gasset's 'The Revolt of the Masses': An Exposition. OmniScience: A Multi-disciplinary Journal, 6(2), 1-8.

Bassey, S. A., \& Mendie, J. G. (2019). Alexis Kagame's Ontological Categories. Cogito: Multidisciplinary Res. J., 11, 52.

Bassey, S., Enang, N. R., \& Mendie, J. G. (2018). Innatism in Locke and the Belief in "OBOT": A Contrastive Study. OmniScience: A Multi-disciplinary Journal, 8(2), 10-17. 
Bryne, P. (1999). The Philosophical and theological Foundations of Ethics: An Introduction to Moral Theory and its Relation to Religious Belief. St. Martin's Press, New York.

Cooper, T. L. (1987). Hierarchy, Virtue, and the Practice of Public Administration: A Perspective for Normative Ethics, Public Administration Review. Vol. 47, No. 4. pp. 320-328.

Eddington, C. (2010). Compassion tempered by Justice, Journal of Psycho-Social Studies. Vol. 4, No. 1, pp. 1-15.

Ferraro, A. E. \& Ajenjo, N. (2014). A Positive Ethics for Pu lic Administration: Altruism, Selfinterest, and the Concept of the State, https://www.researchgate.net/publication/228380466

Festinger, L. (1957). A theory of Cognitive Dissonance. Vol. 2, Stanford University Press, New York.

Frankena, W. K. (1989). Ethics. Prentice-Hall of India, New Delhi.

Frederickson, H. G. (1997). The Spirit of Public Administration. M. E. Sharpe, New York.

Goodnow, F. J. (1997).Municipal Home Rule: A Study in Administration. Macmillan \& Company, New York.

Ikegbu, E. A., \& Bassey, S. A. Ahamefula: discovering leadership gaps of the African being. Multidisciplinary Research Journal, 75.

Ikegbu, E. A., Ogar, J. N., \& Inyang, J. O. (2009). Nigeria's ethnic diversity and its proneness to conflict and violence. Ndunode: Calabar Journals of the Humanities, 8, 109-182.

Lilla, M. (1981). Ethos, Ethics', and Public Service, Public Interest. Vol. 63 (Spring), pp.181225.

MacIntyre, A. (1984). Does Applied Ethics Rest on a Mistake? The Monist. Vol. 67, pp. 499513

Margalit, A. (1996). The Decent Society. Harvard University Press, Cambridge. Mill. J. S. 1858. System of Logic. Harper \& Brothers Publishers, New York.

Ogar, T. E., \& Ogar, J. N. (2018). Globalization in Africa and Beyond: The Quest for Global Ethics. GNOSI: An Interdisciplinary Journal of Human Theory and Praxis, 1(1).

Ogar, T. E., \& Ogar, J. N. (2018). Psycho-Social Factors of Terrorism in Nigeria. GNOSI: An Interdisciplinary Journal of Human Theory and Praxis, 1(1).

Ostrom, E. (2000). Collective Actions and the Evaluation of Social Normsll, Journal of Economic Perspective. Vol. 14, No. 3, pp. 137-158.

Rawls, J. 1980. A Theory of Good. Oxford University Press, Oxford.

Shahzad, K, Murad, H. S., Kitchlew, N. \& Zia, S. A. (2014). Integrating Principles of Care, Compassion, and Justice in Organizations: Exploring Dynamic Nature of Organizational Justicell, Journal of Human Values. Vol. 20 No. 2, 167-181.

Shamsul H. M. (2007). Revisiting the New Public Managementll, Public Administration Review. Vol. 67, No. 1, pp. 179-182.

Sidgwick, H. (1884). Methods of Ethics. Macmillan \& Co., London.

Singer, P. (1993). Practical Ethics. Cambridge University Press, London.

Udoudom, M. D., \& Bassey, S. A. (2018). Plato and John Rawls on Social Justice. Researchers World, 9(3), 110. 